\title{
NASA seeks to move some space science missions off shuttle ...
}

\section{Munich/Washington}

THE National Aeronautics and Space Administration (NASA) is planning to move several science missions now scheduled for launch aboard the space shuttle to expendable launch vehicles (ELVs). One beneficiary of the new plan will be ROSAT, a German X-ray satellite that was supposed to be put into orbit by the US space shuttle this year. Joachim Trümper, director of the Max Planck Institute for Extraterrestrial Physics in Garching, West Germany where ROSAT was developed, says he is operating on the tentative assumption that ROSAT will be launched in 1989 aboard a Delta 2 rocket.

NASA appears to be heeding the cry of many in the space science community to seek ELVs as an alternative to the shuttle. A NASA Advisory Council report released on 12 March urged NASA to seek a mixed fleet for future missions. In addition to ROSAT, NASA now plans to use a Delta 2 to launch two other astrophysics satellites, the extended ultraviolet explorer and the cosmic background explorer. NASA has already found money in its budget to buy the Delta 2 for the cosmic background explorer mission, and is seeking permission from Congress to reallocate $\$ 2$ million from its 1987 budget for ELVs. An item for ELVs may be added for 1988 if the White House Office of Management and Budget approves.
NASA also plans to purchase two Titan 4 rockets. One will be a back-up to the shuttle for either the Galileo mission to Jupiter or the joint Ulysses mission with the European Space Agency to explore the Sun's poles. The other Titan 4 would be used to launch a tracking and data relay satellite now scheduled for a shuttle launch in the $1990 \mathrm{~s}$.

The backlog in shuttle payloads following the Challenger accident would probably have delayed ROSAT until 1994. NASA's decision to use Delta 2 s as launch vehicles follows the Air Force decision to use the same rocket as its primary mediumlaunch vehicle. ROSAT is just inches too broad to fit on top of a regular Delta 2, and a new shroud will have to be designed, at an increased cost of several million dollars. ROSAT programme managers would have preferred using an Atlas Centaur because it is about three inches wider and would not have required any such modification.

There is still a chance that an Atlas Centaur rocket may become available for ROSAT. The National Ocean and Atmospheric Administration (NOAA) is said to be considering buying several Atlas Centaur rockets to launch future weather satellites. This could bring the price down on the Atlas Centaur to make it more competitive with the less expensive Delta 2 .

\section{... and military give ground}

\section{Washington/London/Tokyo}

WARRING factions within the Reagan administration have resolved their differences over how to proceed with negotiations between the United States and its international partners on the manned space station. Disputes had erupted between the National Aeronautics and Space Administration (NASA) and the Defense Department over the use of the space station for military activities.

Negotiations will resume this week in Ottawa with the Canadian space station participants. On 4 May talks resume with Japani, and on 11 May representatives of the European Space Agency (ESA) are due in Washington.

The Pentagon agreed to tone down its demand that the space station be available for possible national security activities following an interagency meeting at the White House on 17 April. A letter from Secretary of Defense Caspar Weinberger to Secretary of State George Shultz had urged that the United States explicitly reserve the right to "conduct national security activities on the US elements of the Space Station, without the approval or review of other nations". The US position now emphasizes that the space station will be used for "peaceful purposes consistent with international law."

ESA has welcomed this as "a positive step forward". But Dr Wilhelm Brado, head of ESA's cabinet, said there were still some problems to be resolved. $\mathrm{Dr}$ Brado says each partner in the space station project will have to decide whether its own national plans comply with the concept of peaceful purposes.

Some of the problems have been left to be sorted out at the agency level in the working agreement between NASA and ESA, according to Dr Brado. The Japanese government, concerned about possible military use of the space station, is being cautious, however. Mr Masahiro Kawasaki, deputy director general of Research and Development at the Science and Technology Agency says that they will be waiting to hear the details at the meeting with the US negotiators next week. "Japan's position has been and still is that the space station should only be used for peaceful purposes", he stressed.

Late last week NASA told contractors

\section{Isis economizes on electricity \\ London}

THE Isis pulsed-neutron facility at the Rutherford Appleton laboratory in Oxfordshire is to close down for six months from September, largely because it cannot afford to pay the electricity bill. Lack of government grants to the Science and Engineering Research Council (SERC), which funds Isis, has resulted in a $£ 2$ million shortfall for the current financial year.

The long-term future of Isis, known until its official inauguration in October 1985 as the spallation neutron source (SNS), now appears to depend on putative European partners jointly funding the facility. In December 1985, memoranda of understanding for such a joint enterprise were signed by France and Italy, and later by Sweden. Interest has been shown by the Netherlands and West Germany. Negotiations are continuing towards an agreement on the constitution of a consortium and levels of funding.

Last year's SERC grant to Isis was £9.97 million, with a further $£ 830,000$ earned from other sources. This year the grant was reduced to $£ 8.5$ million, with a projected income from other sources, including instrumentation from India, Japan and Italy, totalling £1.5 million.

This year's shutdown period, which will include between two and three months for upgrading, will be when electricity tariffs are at their highest. When in full operation, Isis is closed down for two or three months each year for routine maintenance.

The extended closure will have implica. tions for Britain's contribution to the understanding of how high-temperature superconductors work. Dr Donald Paul, of Warwick University, who has been using Isis for neutron-scattering studies on superconductors, says Britain will now start to lag behind its competitors in the rapidly moving field. "It's undoubtedly frustrating," Dr Paul says.

Simon Hadlington

to prepare their bids on various portions of the space station. ESA is expecting to be ready to receive bids once its programme is refined and presented to its ministers in November.

The Defense Department requested late last year that negotiations with international partners be suspended until Pentagon interests could be considered. Once talks resumed, it became clear that military activities aboard the space station could present problems for some countries, and the debate among US agencies has been over how to retain the full range of US interests without jeopardizing international cooperation.

Kathy Johnston, Joseph Palca \& David Swinbanks 